\title{
Using Non-Finites in English Academic Writing by Chinese EFL Students
}

\author{
Bingjun Yang ${ }^{1}$ \\ ${ }^{1}$ Department of English, Southwest University, Chongqing, China \\ Correspondence: Bingjun Yang, Department of English, Southwest University, Chongqing 400715, China. Tel: \\ 86-23-6836-7727. E-mail: bingjunyang@hotmail.com
}

Received: November 21, 2013 Accepted: December 24, 2013 Online Published: January 5, 2014

doi:10.5539/elt.v7n2p42 URL: http://dx.doi.org/10.5539/elt.v7n2p42

\begin{abstract}
Frequent use of non-finites is an important feature of English academic writing (Chafe \& Danielewicz, 1987), but teachers and students in the Chinese environment are not aware of it. To investigate the problems that can be found in academic writings by Chinese students is significant in two aspects: academic writing by Chinese EFL students being largely ignored in literature; writing in English for publishing research being highly demanding in China nowadays. In order to look into how non-finites are represented in academically-oriented English writing by Chinese EFL students, three groups (30 participants in each) of EFL students from three levels of English proficiency (low-level, intermediate and advanced) were requested to participate in the present study. Participants were required to complete a test, following which 45 participants (15 in each group) were selected according to correlations between test results and scores in the nationwide examinations. Forty-five pieces of writing completed by the participants were then investigated in terms of lexical density, non-finite density, distribution of non-finites, and correlation between use of non-finites and writing proficiency. The results show that the use of non-finites is significantly correlated with higher levels of writing proficiency in English. The findings suggest that, as a typical phenomenon in English academic writing, the use of non-finites display distinct interference from the language of non-native writers, and that awareness of and emphasis on non-finites are necessary in the teaching of English writing, academic writing in particular, in the EFL environment.
\end{abstract}

Keywords: non-finites, EFL students, writing, systemic functional

\section{Introduction}

"Research into the English language behaviours and patterns of nonnative academics is beginning to appear" (Flowerdew, 2000, p.127). This is particularly true to the situation of EFL education in China because few focused on English academic writing before 2000 (Yu, 2003). Early studies mostly centered on vocabulary improvement and lexical selection (Santos, 1988). Recent studies have expanded into many other topics. Some introduced Chinese rhetoric and writing in ancient China to the world (Kirkpatrick \& Xu, 2012), and a couple of text-books have recently been published for English academic writing for postgraduates (e.g. Huang, 2006). More recently, scholars began to focus on specific problems. For example, Hirvela and Du (2013) discussed two mainland Chinese students' engagement with paraphrasing in an academic writing course and found that students' understanding of the purposes and functions of paraphrasing influenced their paraphrasing practices in writing.

In the global context, the development of English for Academic Purposes (EAP) in the past 30 years has "reshaped the ways that English language teaching and research are conducted in higher education" (Hyland \& Hamp-Lyons, 2002, p. 1). Different from writing in the everyday sense, academic English writing is "replete with complex syntactic constructions" and "failure to grasp the structural complexities at the sentence level" will bring forth problems in reading and writing (Shin, 2009, p. 401). As an approach to solving the problems, training in sentence-combining is helpful to comprehension, and more importantly, explicit instruction in sentence-combining strategies results in improved writing (e.g. Daiker, Kerek, \& Morenberg, 1985; Saddler \& Graham, 2005).

Complex sentences containing non-finites in sentence-combining are typical but are often underestimated. To use complex sentences in academic text is important for L2 writers at the university level (Hamp-Lyons, 1991), and as one typical but complicated part of complex sentences, non-finites need to be focused for they occupy a large 
proportion in realistic corpus (Egan, 2008). In response to Egan's calling, some recent studies looked into non-finite constructions in old English through corpora (e.g. Timofeev, 2010). Non-finite clauses act as "a bridge between the analysis of simple sentences and that of complex sentences" (Hudson, 1971, p. 105), and high frequency of participles is a distinguishing feature of academic writing (Chafe \& Danielewicz, 1987, p. 102), so a better mastery of non-finites could "help learners to develop a more compact, integrated style" (Granger, 1997, pp. 185-186) in academic writing.

The present study, therefore, is intended to explore the characteristics of non-finites, non-finite clauses in particular, in academically-oriented writings by Chinese EFL students in terms of lexical density, non-finite density, distribution of non-finites, and correlations between use of non-finites and writing proficiency. The theoretical basis is Systemic Functional Grammar (SFG henceforth) by Michael Halliday. We hypothesized that, in academically-oriented tasks, low-level EFL students will use fewer non-finites in their writing than the intermediate students; that the better a piece of writing is, the more evenly non-finite clauses will be distributed across paragraphs; and that there is significant correlation between writing proficiency and the use of non-finites in writings by Chinese EFL students.

\section{Theoretical Basis}

Studies on non-finites casn be grouped into form-based approaches (e.g. Thomson \& Martinet, 1986) and function-based approaches (e.g. Downing \& Locke, 1992). As we can see in the following discussions, SFG as a typical function-oriented approach offers an illuminating and constructive perspective.

\subsection{The Systemic Functional Perspective}

From the perspective of SFG, a non-finite component in English may construct part of a group complex (e.g. try to do), part of a clause complex (e.g. ||| She stopped $\|$ to think $\|||$ ), or an embedded Modifier (e.g. a better person [[to do that $]$ ) (Note that $\| \mid$ is the boundary symbol of a clause complex, $\|$ of a clause, and [[of an embedded clause.) Altogether there are five possibilities of occurrence for a non-finite component in English: (i) nominalisation; (ii) adjectivisation; (iii) verbal group complex; (iv) embedding; and (v) clause complex.

SFG is dominated by function (meaning), in which finite clauses are examined in depth on three dimensions: ideational, interpersonal and textual metafunctions. Non-finite clauses are usually treated as either part of the Mood or the Modal Adjunct, and a comparatively frequent discussion of non-finite clauses in SFG goes to the illustration of hypotactic relations in clause complexes. Based on Halliday and Matthiessen (2004), a non-finite clause may be one of the two types of logico-semantic relation: expansion and projection. Within expansion, a non-finite clause may be employed to elaborate (e.g.: ||| I worked for a local firm at that time, || selling office equipment. |||), extend (e.g.: || Besides missing the wedding, ||she spent the whole week in hospital. |||), or enhance (e.g.: || They must be crazy, || throwing all that good stuff away. |||) a finite clause, or it may be embedded in another element (e.g.: \| the house [being built by Jack] \|); while within projection, it may be projected by the finite clause (e.g.: ||| Mary hopes $\|$ to go to Sweden next year. |||).

\subsection{Criteria for Non-Finite Clause Identification}

A number of non-finite constructions in English are not readily classifiable according to the occurrences and types stated above, for "Non-finites are hard to identify" (Halliday, 1993, 2005, p. 147). For example, clauses with infinitivals such as the man to fix the sink look like the clause the book to read, but they are structurally different (Bhatt, 2006, p. 3). The fact that finiteness properties in independent clauses may occur in any combination (Nikolaeva, 2007, p. 138) increases the difficulties in identification.

Within SFG, Yang (2004, pp. 233-249) proposed four criteria of non-finite clause identification, which may be used to tackle the problems. Following the idea that the relation between clauses in a clause complex is a relation between processes proposed by Halliday (1994), Yang (2004) proposed four criteria of non-finite clause identification as follows. The first, the process-oriented criteria, includes the "number of processes" criterion and the "order of processes" criterion. It is found that the "number of processes" helps distinguish verbal group complex from embedding and clause complex, for there is only one process in a verbal group complex and the process type is usually determined by the latter component of the complex. See (1) as follows:

(1) Frank sat reading the newspaper (Quirk et al., 1985, p. 1126).

In (1), there are two participants for the process realised by sat, one being overt (Frank) and the other being covert (i.e., in the chair). Likewise, there are two participants (Frank and the newspaper) realised by reading. The number of processes is more than one in this construction where there is a finite clause and a non-finite component, so it is a clause complex when embedding is excluded. 
The "order of processes" affects the status of non-finite components and a change in the order may result in constructions of different status. Usually the construction becomes a clause complex when the process expressed by the non-finite component can precede the finite clause. For example:

(2) He agreed to marry Jimena Diaz (London-Oslo-Bergen Corpus, LOB).

The status of (2) as a clause complex becomes apparent when the order of the processes in the construction is reversed: To marry Jimena Diaz, he agreed. The construction may be a clause with a verbal group complex if agreed comes before marry, and in that case agreed to marry realises one single process.

The second, the participant-oriented criterion, is that there should be at least one covert participant and one overt participant if a construction containing a non-finite component is to achieve the status of a clause complex. The two participants belong to two different processes and must not be identical when there is only one overt participant and one covert participant. Take (1) as an example. In (1), there is one overt participant (Frank) and one covert participant (in the chair) for the process sat; and two overt participants (the newspaper and Frank) for the process reading. Therefore, the construction is a clause complex although it appears to be a clause.

The third, the relator-oriented criterion, suggests that if a conjunction can be inserted before the non-finite component, then the construction is likely to be a clause complex. For example, when a relator in order is inserted in (2) and becomes He agreed in order to marry Jimena Diaz, the construction obviously becomes a clause complex.

On the interpersonal level, as a fourth criterion, the Modal Adjunct "not" can be employed to identify non-finite clauses. A non-finite component which can be preceded by the Modal Adjunct "not" is very likely to be a non-finite clause, either embedded or dependent. For example, (2) and similar constructions like Pardao will be easy to beat (LOB) may have two interpretations respectively, but only one interpretation is acceptable when the Modal Adjunct "not" is inserted before the non-finites. It is a simple fact that we cannot take agreed not to marry or will be easy not to beat as verbal group complexes because "not" disconnects the finite and non-finite components.

In the same manner, such constructions discussed by Bhatt (2006) as the man to fix the sink and the book to read can be functionally (semantically) distinguished, non-finite in the former clause being rankshifted to function as a group because not cannot be inserted before to fix the sink, and non-finite in the latter clause being a clause itself because not can be inserted before to read. The identification of non-finites in the present investigation will follow these criteria and the treatments will be based on SFG.

\section{Method}

\subsection{Participants}

Thirty first-year EFL students from Southwest University who scored between 40 and 60 points (on a 100-point scale) in English Test Band Four (Approximately equal to IELTS 3), a nationwide English test held in China, took part in the study. Thirty third-year EFL students from Southwest University who scored between 70 and 90 points in English Test Band Six (Approximately equal to IELTS 5), a nationwide English test held in China, also participated in the study. Thirty EFL postgraduates from Southwest University, who major in English linguistics and who passed English Test Band Eight (Approximately equal to IELTS 7) for English majors, were required to take part in the study. All participants were given credits for their average performance in English-related courses.

\subsection{Research Design}

Materials include score records in National English Tests Band Four and Band Six for non-English majors and in English Test Band Eight for English majors. SPSS 16.0 was used for data analysis, and Wordsmith Tools 3.0 was used for the basic statistics of the writings. Calculations of non-finites based on SFG and the four criteria of non-finite clause identification were completed manually.

As was mentioned above, there are five possibilities of occurrence for a non-finite component in English from the SFG perspective. To avoid possible confusion with nouns and adjectives, we excluded nominalisation and adjectivisation in this study. In other words, non-finites here refer to verbal group complex, embedding and non-finite clauses. Take two sentences written by participants as an example:

(3) There are many things need "Practice Makes Perfect", dancing, singing, swimming, cooking and so on.

(4) There is a new word that we didn't learn ago, but we can guess its mean according to our learning knowledge. 
Non-finites "dancing, singing, swimming, cooking" in (3) are all regarded as nominalisations because they do not rise to be clause in rank, and "learning" in (4) is considered as adjectivisation because it only serves as a modifier of "knowledge". Such non-finites were excluded in the investigation.

The study includes a selection test and data collection. In the selection test, all the 90 participants were required to write an essay about "Global Shortage of Fresh Water", and an experienced teacher who is a native speaker other than the researcher was paid to score the writings. Then, 45 participants whose scores are positively correlated with the scores they received in the nation-wide tests were selected. As was expected, the bottom 15 turned out to be first-year students, the middle 15 to be third-year students, and the top 15 to be postgraduates. The three groups were then labelled Group A (low-level), Group B (intermediate) and Group C (advanced) respectively in the formal test.

In the formal test, all participants selected were required to write 'academically' on the title "Practice Makes Perfect". Note that only a few postgraduates doing sciences in China conduct academic writing sometimes, and most works they have published in English were translated from the Chinese "originals" by individual professionals or translation companies. Difficulties to get papers published in English is considerable for Chinese scholars as a whole (Flowerdew, 2000; Gosden, 2003; Cited in Cargill \& O'Connor, 2006, p. 208). Such restrictions confined the selection of participants and the requirements of writing in academic English. In order to minimize the restrictions, the participants were exposed to 10 academic articles without explanation beforehand, and in the formal test they were required to write 'academically' on the topic which was familiar to them, i.e. Practice Makes Perfect. The Instructions to the participants clearly stated that participants should write as formally as possible in the academic way. The same experienced teacher other than the researcher was paid to score the writings. The tests were performed in the same classroom within the same limit of time (30 minutes). After data collection, nine variables in each passage written by participants were calculated, i.e., number of words, number of sentences, number of clauses, lexical items, -ing clauses, to- clauses, -ed clauses, verbal group complex, and errors in non-finites. For example, the following passage was written by Participant No. 10 in Group C (Note that non-finites are indicated in bold brackets.):

(5) "Practice makes perfect" can be found among the proverbs in both the English and Chinese languages. When learning something [-ing clause], we are frequently told to practise [to- clause] more because practice makes perfect, but how to understand this proverb [to- clause]? In my opinion, this proverb means that the more you practise something, the better you master it and the more likely you can innovate it.

For example, in our English study, practice is very important if we want to improve [verbal group complex] our spoken English. When coming to a new expression [-ing clause], we recite it again and again until we can say it fluently. Through such practice, not only do we master the structure of the expression but also we can understand the exact meaning, knowing its usage [-ing clause]. Then we try it out in every situation when we think it is proper. Finally, we may be able to use [verbal group complex] this expression combined with other expressions [-ed clause] or we may be able to find [verbal group complex] some new ways to use the expression [to- clause]. So "practice makes perfect" works.

"Practice makes perfect" also works in designing computer program [-ing clause]. Through many times practice, we face failures and we solve problems and finally we get the program working [-ing clause]. Then we practice it again and again, finding its disadvantages [-ing clause] and improving it [-ing clause]. Finally we may wok out a program well-designed for use [-ed clause].

Actually, "practice makes perfect" almost works in every field. It can serve as a common approach to every thing we want to learn [verbal group complex].

Although there are still problems in some expressions (e.g. the beginning sentence), this piece of writing contains 14 properly-used non-finites: 7 -ing clauses, 3 to- clauses, 2 -ed clauses and 2 verbal group complexes. Repetitions of the same type (i.e. "want to" and "be able to" in this writing) of verbal group complex were counted only once.

\section{Results}

It is necessary to provide the elementary data collected in the investigation, i.e. number of words, number of sentences, number of clauses, and lexical items the participants produced in the formal test (See Table 1). In order to make comparisons, scores the participants received in the selection test are also shown in the table. 
Table 1. Writing results in the formal test and scores in the selection test

\begin{tabular}{llccccc}
\hline & & Words & Sentences & Clauses & Lexical items & Scores in the selection test \\
\hline \multirow{2}{*}{ Group A } & Mean & 132.13 & 11.33 & 21.53 & 43.67 & 53.73 \\
& Sum & 1982 & 170 & 323 & 655 & 806 \\
\hline \multirow{2}{*}{ Group B } & Mean & 160.73 & 13.00 & 24.53 & 54.67 & 73.60 \\
& Sum & 2411 & 195 & 368 & 820 & 1104 \\
\hline \multirow{2}{*}{ Group C } & Mean & 213.47 & 14.20 & 34.13 & 67.53 & 88.60 \\
& Sum & 3202 & 213 & 512 & 1013 & 1329
\end{tabular}

Note: Scores in the selection test were measured on a 100-point scale

Since the purpose of the study is to reveal the characteristics of non-finites, non-finites produced by the participants are shown in Table 2 below. The correct uses of non-finites by the participants are also shown in the table.

Table 2. Summary of non-finites the participants produced

\begin{tabular}{llcccccccc}
\hline & & $\begin{array}{c}\text {-ing } \\
\text { clauses }\end{array}$ & $\begin{array}{c}\text { to- } \\
\text { clauses }\end{array}$ & $\begin{array}{c}\text {-ed } \\
\text { clauses }\end{array}$ & $\begin{array}{c}\text { verbal } \\
\text { group } \\
\text { complexes }\end{array}$ & $\begin{array}{c}\text { correct } \\
\text { uses of } \\
\text {-ing } \\
\text { clauses }\end{array}$ & $\begin{array}{c}\text { correct } \\
\text { uses of } \\
\text { to- } \\
\text { clauses }\end{array}$ & $\begin{array}{c}\text { correct } \\
\text { uses of } \\
\text {-ed } \\
\text { clauses }\end{array}$ & $\begin{array}{c}\text { correct uses } \\
\text { of verbal } \\
\text { group } \\
\text { complexes }\end{array}$ \\
\hline \multirow{2}{*}{ Group A } & Mean & .93 & .87 & .00 & 1.07 & .40 & .67 & .00 & .80 \\
& Sum & 14 & 13 & 0 & 16 & 6 & 10 & 0 & 12 \\
\hline \multirow{2}{*}{ Group B } & Mean & 1.80 & 2.47 & .13 & 1.40 & 1.33 & 2.27 & .13 & 1.33 \\
& Sum & 27 & 37 & 2 & 21 & 20 & 34 & 2 & 20 \\
\hline \multirow{2}{*}{ Group C } & Mean & 4.47 & 3.60 & 1.07 & 1.93 & 4.47 & 3.60 & 1.07 & 1.87 \\
& Sum & 67 & 54 & 16 & 29 & 67 & 54 & 16 & 28 \\
\hline
\end{tabular}

With these data, lexical density, clause density, non-finite clause density, verbal group complex density, distribution of non-finites, and correlation between use of non-finites and English proficiency were analysed, each of which serves to show how Chinese EFL learners use non-finites in academic English writing.

According to Halliday and Matthiessen (2004, p. 655), "To measure lexical density, simply divide the number of lexical items by the number of ranking clauses". The results show that the mean lexical density of Groups A, B and $\mathrm{C}$ was $2.033,2.283$, and 2.038 respectively.

Clause density is concerned with both finite clause and non-finite clause, and it can be measured by dividing the number of clauses by the number of sentences. The mean clause density of Groups A, B and C was 1.995, 1.986, and 2.462 respectively.

Similar to the calculation of lexical density, -ing clause density can be measured by dividing the number of -ing clauses by the number of clauses. The mean -ing clause density of writings by Groups A, B and C was .047, .077, and .132 respectively. Note that the calculation of the following variables includes only the grammatically-used non-finites unless otherwise stated.

Based on the method of calculating lexical density, non-finite to- clause density was measured by dividing the number of to- clauses by the number of clauses. The mean non-finite to- clause density of writings was $.037, .098$ and .109 for low-level, intermediate and advanced participants.

Non-finite -ed clause density can be measured by dividing non-finite -ed clauses by the number of clauses. The mean density of writings by Groups A, B and C was $.000, .007$, and .030 respectively. In other words, not even an instance can be found in the writings by low-level students, and both intermediate and advanced students only used a few -ed clauses.

Group complex ranks below clauses, so the density of verbal group complex may be calculated in more than one way. In order to be consistent, verbal group complex density was measured by dividing the number of verbal 
group complexes by the number of clauses. The mean density of correct verbal group complexes in writings by Groups A, B, and C was .048, .053 and .058 respectively.

Since there were a number of errors in the use of non-finites in the participants' writings, we distinguished two types of non-finites: potential and proper. Potential non-finites refer to all non-finite clauses and verbal group complexes that appear in the participants' writings, including ungrammatically used ones. Proper non-finites refer to all non-finite clauses and verbal group complexes used grammatically. The distribution of potential and proper non-finites is shown in Table 3.

Table 3. Potential and proper non-finites in writings by three groups

\begin{tabular}{llcccccccc}
\hline & & $\begin{array}{c}\text {-ing } \\
\text { clauses }\end{array}$ & $\begin{array}{c}\text { to- } \\
\text { clauses }\end{array}$ & $\begin{array}{c}\text {-ed } \\
\text { clauses }\end{array}$ & $\begin{array}{c}\text { verbal } \\
\text { group } \\
\text { complexes }\end{array}$ & $\begin{array}{c}\text { correct } \\
\text { uses of } \\
\text {-ing } \\
\text { clauses }\end{array}$ & $\begin{array}{c}\text { correct } \\
\text { uses of } \\
\text { to- } \\
\text { clauses }\end{array}$ & $\begin{array}{c}\text { correct } \\
\text { uses of } \\
\text {-ed } \\
\text { clauses }\end{array}$ & $\begin{array}{c}\text { correct uses } \\
\text { of verbal } \\
\text { group } \\
\text { complexes }\end{array}$ \\
\hline \multirow{2}{*}{ Group A } & & & & & & & & & \\
& Mean & .93 & .87 & .00 & 1.07 & .40 & .67 & .00 & .80 \\
& Variance & .638 & .838 & .000 & 1.638 & .400 & .667 & .000 & 1.314 \\
& Grp. Median & .91 & .75 & .00 & .80 & .36 & .58 & .00 & .58 \\
& SD & .799 & .915 & .000 & 1.280 & .632 & .816 & .000 & 1.146 \\
\hline \multirow{3}{*}{ Group B B } & Bean & 1.80 & 2.47 & .13 & 1.40 & 1.33 & 2.27 & .13 & 1.33 \\
& Variance & 1.457 & 2.981 & .124 & 1.829 & 1.524 & 2.638 & .124 & 1.952 \\
& Grp. Median & 1.70 & 1.89 & .13 & 1.22 & 1.25 & 1.80 & .13 & 1.12 \\
& SD & 1.207 & 1.727 & .352 & 1.352 & 1.234 & 1.624 & .352 & 1.397 \\
\hline \multirow{6}{*}{ Group C } & Mean & 4.47 & 3.60 & 1.07 & 1.93 & 4.47 & 3.60 & 1.07 & 1.87 \\
& Variance & 4.552 & 1.971 & .781 & .781 & 4.552 & 1.971 & .781 & .695 \\
& Grp. Median & 4.33 & 3.30 & 1.10 & 2.00 & 4.33 & 3.30 & 1.10 & 1.91 \\
& SD & 2.134 & 1.404 & .884 & .884 & 2.134 & 1.404 & .884 & .834 \\
\hline
\end{tabular}

In order to test the correlations, we performed an ANOVA test of the scores in the selection test and the use of non-finites in the formal test (See Table 4). Since only participants whose scores in the selection test were positively correlated with the scores in nationwide examinations were finally selected as participants in the formal test, the reliability can be maintained.

Table 4. ANOVA test of scores in the selection test and use of non-finites in the formal test

\begin{tabular}{llccccc}
\hline & & Sum of Squares & df & MS & F & Sig. \\
\hline \multirow{4}{*}{-ing clauses } & Between Groups & 160.967 & 29 & 5.551 & 2.461 & .035 \\
& Within Groups & 33.833 & 15 & 2.256 & & \\
& Total & 194.800 & 44 & & & \\
\hline \multirow{4}{*}{ to- clauses } & Between Groups & 102.478 & 29 & 3.534 & 1.507 & .203 \\
& Within Groups & 35.167 & 15 & 2.344 & & \\
& Total & 137.644 & 44 & & & \\
\hline \multirow{3}{*}{-ed clauses } & Between Groups & 18.467 & 29 & .637 & 2.204 & .055 \\
& Within Groups & 4.333 & 15 & .289 & & \\
& Total & 22.800 & 44 & & & \\
\hline \multirow{2}{*}{ verbal group } & Between Groups & 51.033 & 29 & 1.760 & 1.863 & .103 \\
& Within Groups & 14.167 & 15 & .944 & & \\
& Total & 65.200 & 44 & & & \\
\hline
\end{tabular}


After errors in the use of non-finites were excluded, we performed another ANOVA test of scores in the selection test and correct uses of non-finites in the formal test (See Table 5). The results confirm part of what is shown in Table 4 above: Scores participants received in the selection test are significantly correlated with correct uses of non-finite -ing clauses, -ed clauses, and verbal group complexes, but not with that of to- clauses.

Table 5. ANOVA test of scores in the selection test and correct uses of non-finites in the formal test

\begin{tabular}{|c|c|c|c|c|c|c|}
\hline & & Sum of Squares & $\mathrm{df}$ & MS & $\mathrm{F}$ & Sig. \\
\hline \multirow{3}{*}{$\begin{array}{l}\text { Correct uses of } \\
\text {-ing clauses }\end{array}$} & Between Groups & 196.633 & 29 & 6.780 & 3.371 & .008 \\
\hline & Within Groups & 30.167 & 15 & 2.011 & & \\
\hline & Total & 226.800 & 44 & & & \\
\hline \multirow{3}{*}{$\begin{array}{l}\text { Correct uses of } \\
\text { to- clauses }\end{array}$} & Between Groups & 111.244 & 29 & 3.836 & 2.105 & .065 \\
\hline & Within Groups & 27.333 & 15 & 1.822 & & \\
\hline & Total & 138.578 & 44 & & & \\
\hline \multirow{3}{*}{$\begin{array}{l}\text { Correct uses of } \\
\text {-ed clauses }\end{array}$} & Between Groups & 18.467 & 29 & .637 & 2.204 & .055 \\
\hline & Within Groups & 4.333 & 15 & .289 & & \\
\hline & Total & 22.800 & 44 & & & \\
\hline \multirow{3}{*}{$\begin{array}{l}\text { Correct uses of } \\
\text { verbal group } \\
\text { complexes }\end{array}$} & Between Groups & 53.833 & 29 & 1.856 & 2.739 & .022 \\
\hline & Within Groups & 10.167 & 15 & .678 & & \\
\hline & Total & 64.000 & 44 & & & \\
\hline
\end{tabular}

The use of non-finite -ing clauses are significantly correlated with the scores participants received in the selection test $(F=2.461$; d.f. $=29 ; p=.035)$, and the use of non-finite -ed clauses are also significantly correlated with the scores participants received in the selection test $(F=2.204$; d.f. $=29 ; p=.055)$. Different from -ing and -ed clauses, uses of non-finite to- clauses and verbal group complexes are not significantly correlated with the scores participants received in the selection test $(F=1.507$; d.f. $=29 ; p=.203$ for to- clauses and $F=1.863$; d.f. $=29 ; p=.103$ for verbal group complexes).

\section{Discussions}

The results suggest that no significant difference was found in lexical density of writings by low-level and advanced participants. It was usually believed that the more formal a piece of writing is, the denser is its lexical density. However, writings by intermediate students are higher in lexical density than those written by advanced participants $(2.283: 2.038)$. The reason may lie in the difference in number of clauses and words in writings. Compared with advanced participants, intermediate participants write sentences with fewer clauses. Writings by low-level participants and intermediate participants are close in clause density while those by advanced participants are much higher in clause density. Low-level participants write shorter sentences when compared with intermediate participants. Intermediate participants are better at producing more lexical items in a sentence, but sentences they write carry more clauses, which results in lower clause density. Advanced participants can produce far more clauses in fewer but longer sentences, so clause density in their writings is the highest. In other words, the ability to produce clauses in a sentence is quite different between advanced students and the other two groups of students.

Low-level and intermediate participants are not good at using non-finite -ing clauses, and advanced participants use non-finite clauses more frequently in a more proficient way. Low-level learners are able to produce a number of -ings, which seems to indicate that low-level learners are already aware of non-finite -ings, but the problem is that many non-finite -ing clauses they produce are ungrammatical (e.g. After reading many books and remembering words as a full sentence). Moreover, most cases of non-finites belong to nominalisation and adjectivisation (e.g. Our reading and writing skills can be improved more quickly).

From the results, we can see that intermediate learners almost use non-finite to- clauses as frequently as advanced learners do. There is not much difference in the ability to produce non-finite to- clauses between intermediate and advanced learners, but a further look into the accuracy and appropriateness reveals that intermediate learners are not proficient in using non-finite to- clauses yet (e.g. when a teacher advises his 
students or parents educate their children). Overall, three groups of different English proficiency use non-finite to- clauses more often they use -ing clauses, but only Group C, i.e., advanced students, have preferably learned to use to- clauses well enough in their writing.

Low-level learners have not acquired the ability to use non-finite -ed clauses in their writing. A few intermediate learners occasionally used -ed clauses, which indicates the learners' unfamiliarity in -ed clauses. Compared with intermediate students, advanced students used much more non-finite -ed clauses, but they still use -ed clauses cautiously, for they prefer finite clauses where -ed clauses can be used.

Low-level learners use verbal group complexes almost as often as intermediate and advanced learners do. However, in writings by low-level learners, more than a half of verbal group complexes belong to "want to" construction, which corresponds with xiangyao qu, a frequently used expression in the Chinese language which means "want to". In writings by intermediate and advanced learners, about 1 out of 3 verbal group complexes belongs to "want to" construction. This indicates simplicity and lack of variety in the use of verbal group complexes in writings by the participants.

It can be inferred from the distributional tendency that the better a student writes, the more non-finites he/she will use, non-finite -ing clauses in particular; that the more proficient the students are in English, the more evenly non-finites they use will be distributed across paragraphs. To- clauses, comparatively speaking, are well-distributed across paragraphs in writings by the participants. This is not because these students are proficient in the use of to- clauses but the interference of the frequently used Chinese phrase xiangyaoqu, which means "want to go/do" in English. What is more, a construction in Chinese which is called "liandong construction" is similar in structure to verbal group complex, but in the Chinese construction at least two verbs and two nouns are needed while the English verbal group complex is generally composed of two verbs connected by "to". This similarity, too, results in the comparatively frequent use of verbal group complexes in writings by the participants.

Unsatisfactory correlations found in to- clauses may be due to the interference of $q u$ in Chinese, a frequently used verb in the Chinese language. As was explained in 4.7 above, xiangyaoqu and "liangdong construction" interfere much with constructions containing "to do" and "want to do" in English. For example, in the popular English-Chinese dictionaries, "to" is translated into $q u$ in Chinese. Interfered by such usages, the low-level learners use to- clauses very often in their writing, though with many errors (e.g. This example is told us practice makes perfect).

Effective use of non-finites helps improve the quality of EFL writing but learners should be trained before they can use non-finites effectively. The underlying reasons of Chinese EFL students' unsatisfactory use of non-finites may be as follows. Firstly, the Chinese language "has nothing to do with finite or non-finite clauses" (Hu, 1990, p. 23), or at least Chinese has a totally different system of conception of writing (Rijlaarsdam, 2005, p. 8). Secondly, the complexity of logico-semantics of some non-finite clauses causes much difficulty to EFL learners. For example, I heard the water lapping on the crag is different from Mary considers John to be responsible. The former is a construction formed out of a fusion of two clauses, but the latter is a clause in which the non-finite clause functions as a Meta-phenomenon. Viewed from the rank scale based on SFG, the former involves clause combination into a complex while the latter involves rankshift. Thirdly, the status of non-finite clauses is intermediate itself, resulting in uncertain categorisation. Non-finite clauses are intermediate between the most congruent forms realised as clause complex with finite clauses (e.g. Peter translated the book when he was young.) and the most metaphorical forms realised by nominalisation (e.g. Peter's translating of the book). Some non-finite clauses are themselves grammatical metaphors (e.g. Seeing is believing), which adds to their semantic difficulty in application for EFL learners.

In teaching of non-finites, -ed clauses should be emphasized so that EFL students can use them more often; verbal group complex and to- clauses should be extended so that EFL students can use them more diversely; and -ing clauses should be enhanced so that EFL students can use them more appropriately. EFL students in China should be taught to use to- clauses and verbal group complexes more cautiously. Teachers may open lectures on the use of non-finites in academic writing before students begin to write academically. Incorrect uses of non-finites need to be corrected and confusing constructions need to be made clear to the students.

Obviously, to write academically is not simply to master a set of transferable rules. Without explicit instruction in the structural aspects of academic language, ESL students cannot access grade-level content, which leads to academic underperformance (Wong, Fillmore, \& Snow, 2000). Teachers should teach students how to use complex syntactic constructions (Harley \& Swain, 1984; Swain, 1995), and ESL students need to concentrate on form, in addition to engaging in communicative language use (Swain, 1995; Doughty \& Williams, 1998; Hinkel, 
2004), so that non-finites can be learned in either sentential or textual contexts. Moreover, genre-based pedagogies offer a valuable resource for assisting writing instructors to teach their students how to produce effective and relevant texts (Hyland, 2007), and EAP type courses proper can have a positive impact on students' writing (Storch \& Tapper, 2009). Both teachers and students should be well aware that "Writing is integral to language learning, the development of literacy, and performance in programs of academic study" (Cumming, 2006, p. 1) and it "is cognitively complex, involving multiple attentional demands, strategies, and processes, yet it is also affective involving intentionality and self-expression." (Lavelle, 2007, p. 219). Apart from these preparations, the composition of a writer's social network (Ferenz, 2005) and individualism (Ramanathan \& Atkinson, 1999) affects advanced academic writing. In other words, many other factors can be investigated in the Chinese EFL context, the negotiation of complex power relations (See Hyland \& Hyland, 2012) for example. Generally speaking, key issues which dominate current understandings of writing include context, literacy, culture, technology, genre and identity (Hyland, 2009) and all these issues within academic writing can be researched further in the Chinese EFL environment.

Here we can conclude that, the better a student writes, the more non-finites he/she will use, and that Chinese learners' proficiency in English is significantly correlated with correct uses of non-finite -ing clauses, -ed clauses, and verbal group complexes in their writings. Some may argue that, if English is to continue to function as a "lingua franca", some Chineseness in China English has its rationale (See Ma, 2012), but the findings here and the literature suggest that both grammatical and lexical features of writings by Chinese EFL students should be focused first. Since non-finites is a good indicator of writing complexity and academic writing proficiency, due attention should be paid to their use both in sentence combining exercises and in teaching expository writing. In the future, comparisons of non-finites between native and non-native learners in academic writing can be done with reference to such corpora as the British Academic Written English (BAWE) corpus by Hilary Nesi, Sheena Gardner, Paul Thompson, and Paul Wickens, and related research is expected to go deeper.

\section{Acknowledgements}

We would like to thank the anonymous reviewers for their thoughtful comments. This research is supported by the Program for New Century Excellent Talents in University from China Ministry of Education (NCET-11-0704) and the Fundamental Research Funds for the Central Universities (SWU1409102).

\section{References}

Bhatt, R. (2006). Covert modality in non-finite contexts. Berlin: Walter de Gruyter.

Cargilla, M., \& O'Connor, P. (2006). Developing Chinese scientists' skills for publishing in English: Evaluating collaborating-colleague workshops based on genre analysis. Journal of English for Academic Purposes, 5, 207-221. http://dx.doi.org/10.1016/j.jeap.2006.07.002

Cargill, M. A., \& O'Connor, P. J. (2012). Identifying and addressing challenges to international publication success for EFL science researchers: Implementing an integrated training package in China (pp. 21-44). In R. Tang (Ed.), Academic writing in a second or foreign language: Issues and challenges facing ESL/EFL academic writers in higher education contexts. London: Continuum.

Chafe, W., \& Danielewicz, J. (1987). Properties of spoken and written language. In R. Horowitz, \& S. J. Samuels (Eds.), Comprehending oral and written language (pp. 83-113). Sand Diego: Academic Press.

Cumming, A. (2006). Introduction, purpose, and conceptual foundations. In A. Cumming (Ed.), Goals for academic writing: ESL students and their instructors (pp. 1-18). New York: John Benjamins.

Daiker, D. A., Kerek, A., \& Morenberg, M. (1985). Sentence combining: A rhetorical perspective. Carbondale and Edwardsville: Southern Illinois University Press.

Doughty, C., \& Williams, J. (1998). Focus on form in classroom second language acquisition. Cambridge: Cambridge University Press.

Downing, A., \& Locke, P. (1992). A university course in English grammar. Englewood Cliffs: Prentice Hall.

Egan, T. (2008). Non-finite complementation: A usage-based study of infinitive and -ing clauses in English. Amsterdam: Rodopi B.V.

Ferenz, O. (2005). EFL writers' social networks: Impact on advanced academic literacy development. Journal of English for Academic Purposes, 4, 339-351. http://dx.doi.org/10.1016/j.jeap.2005.07.002

Flowerdew, J. (2000). Discourse community, legitimate peripheral participation, and the nonnative-English-speaking scholar. TESOL Quarterly, 24, 127-150. http://dx.doi.org/10.2307/3588099 
Granger, S. (1997). On identifying the syntactic and discourse features of participle clauses in academic English: Native and non-native writers compared. In J. Aarts, I. de Mönnink, \& H. Wekker (Eds.), Studies in English language and teaching (pp. 185-198). Amsterdam and Atlanta: Rodopi.

Halliday, M. A. K. (1993, 2005). Quantitative studies and probabilities in grammar. In J. Webster (Ed.), Computational and quantitative studies, Volume 6 in the collected works of M. A. K. Halliday (pp. 130-150). London: Continuum.

Halliday, M. A. K. (1994). An introduction to functional grammar (2nd ed.). London: Arnold.

Halliday, M. A. K., \& Matthiessen, C. (2004). An introduction to functional grammar (3rd ed.). London: Arnold.

Hamp-Lyons, L. (1991). Scoring procedures for ESL contexts. In L. Hamp-Lyons (Ed.), Assessing second language writing (pp. 241-277). Norwood, NJ: Ablex.

Harley, B., \& Swain, M. (1984). The interlanguage of immersion students and its implications for second language teaching. In A. Davies, C. Criper, \& A. Howatt (Eds.), Interlanguage (pp. 291-311). Edinburgh: Edinburgh University Press.

Hinkel, E. (2004). Teaching academic EFL writing: Practical techniques in vocabulary and grammar. New York: Lawrence Erlbaum Associates.

Hirvela, A., \& Du, Q. (2013). Why am I paraphrasing? Undergraduate ESL writers' engagement with source-based academic writing and reading. Journal of English for Academic Purposes, 12(2), 87-98. http://dx.doi.org/10.1016/j.jeap.2012.11.005

Hu, Z. L. (1990). Clause and clause complex. In Z. L. Hu (Ed.), Language system and function (pp. 1-16). Beijing: Peking University Press.

Huang, G. W. (2006). English academic writing. Chongqing: Chongqing University Press.

Hudson, R. A. (1971). English complex sentences. Amsterdam: North-Holland.

Hyland, K. (2007). Genre pedagogy: Language, literacy and L2 writing instruction. Journal of Second Language Writing, 16, 148-164. http://dx.doi.org/10.1016/j.jslw.2007.07.005

Hyland, K. (2009). Teaching and researching writing. Harlow: Pearson Education Limited.

Hyland, K., \& Hamp-Lyons, L. (2002). EAP: Issues and directions. Journal of English for Academic Purposes, 1, 1-12. http://dx.doi.org/10.1016/S1475-1585(02)00002-4

Hyland, K., \& Hyland, F. (2012). You could make this clearer: Teachers' advice on ESL academic writing (pp. 53-72). In H. Limberg, \& M. A. Locher (Eds.), Advice in discourse. Amsterdam: John Benjamins.

Kirkpatrick, A., \& Xu, Z. (2012). Chinese rhetoric and writing: An introduction for language teachers. Colorado: Fort Collins.

Lavelle, E. (2007). Approaches to writing. In M. Torrance, L. van Waes, \& D. Galbraith (Eds.), Writing and cognition: Research and applications (pp. 219-230). Oxford: Elsevier.

Ma, Q. (2012). Upholding standards of academic writing of Chinese students in China English. Changing English: Studies in Culture and Education, 19(3), 349-357. http://dx.doi.org/10.1080/1358684X.2012.704585

Nikolaeva, I. (2007). Constructional economy and nonfinite independent clauses. In I. Nikolaeva (Ed.), Finiteness: Theoretical and empirical foundations (pp. 138-182). New York: Oxford University Press.

Quirk, R., Greenbaum, S., Leech, G., \& Svartvik, J. (1985). A comprehensive grammar of the English Language. London: Longman.

Ramanathan, V., \& Atkinson, D. (1999). Individualism, academic writing, and ESL writers. Journal of Second Language Writing, 8(1), 45-75. http://dx.doi.org/10.1016/S1060-3743(99)80112-X

Rijlaarsdam, G. (2005). Preface. In M. S. K. Shum, \& D. L. Zhang (Eds.), Teaching writing in Chinese speaking areas (pp. 7-9). London: Springer.

Saddler, B., \& Graham, S. (2005). The effects of peer-assisted sentence-combining instruction on the writing performance of more and less skilled young writers. Journal of Educational Psychology, 97, 43-54. http://dx.doi.org/10.1037/0022-0663.97.1.43

Santos, T. (1988). Professors' reactions to the academic writing of nonnative-speaking students. TESOL Quarterly, 22(1), 69-90. http://dx.doi.org/10.2307/3587062 
Shin, S. J. (2009). Negotiating grammatical choices: Academic language learning by secondary ESL students. System, 37, 391-402. http://dx.doi.org/10.1016/j.system.2009.01.002

Storch, N., \& Tapper, J. (2009). The impact of an EAP course on postgraduate writing. Journal of English for Academic Purposes, 8, 207-223. http://dx.doi.org/10.1016/j.jeap.2009.03.001

Swain, M. (1995). Three functions of output in second language learning. In G. Cook, \& B. Seidhofer (Eds.), For H. G. Widdowson: Principles and practice in the study of language (pp. 125-144). Oxford: Oxford University Press.

Thomson, A. J., \& Martinet, A. V. (1986). A practical English grammar. Oxford: Oxford University Press.

Timofeeva, O. (2010). Non-finite constructions in old English: With special reference to syntactic borrowing from Latin (PhD dissertation, University of Helsinki).

Wong, F. L., \& Snow, C. E. (2000). What teachers need to know about language. ERIC Clearinghouse on Languages and Linguistics. Washington: U.S. Department of Education.

Yang, B. J. (2004). Towards the criteria of non-finite clause identification. Language Sciences, 26(3), 233-249. http://dx.doi.org/10.1016/j.langsci.2003.07.002

Yu, H. (2003). Discourse as genre: Arresting semiotics in research paper abstracts. Kaifeng: Henan University Press.

\section{Copyrights}

Copyright for this article is retained by the author(s), with first publication rights granted to the journal.

This is an open-access article distributed under the terms and conditions of the Creative Commons Attribution license (http://creativecommons.org/licenses/by/3.0/). 